\title{
STUDI PENGENDALIAN BANJIR DI KOTA BARABAI TERKAIT RENCANA PEMBANGUNAN BENDUNGAN PANCUR HANAU DI SUNGAI BARABAI KABUPATEN HULU SUNGAI TENGAH
}

\author{
Eddy Prabowo 1 \\ ${ }^{1}$ PT. Bumi Kahuripan Jaya Malang
}

\begin{abstract}
ABSTRAK
Banjir besar melanda Kota Barabai pada bulan juni tahun 2013, dimana kejadian ini mengakibatkan kerusakan di sempadan sungai dan banjir menggenangi Kota Barabai. Curah hujan dan ketinggian muka air Sungai Barabai pada saat kejadian banjir tersebut sempat terekam oleh Pos Automatic Water Level Recorder (AWLR) Baruh Batung yang terletak di Kecamatan Hantakan Kabupaten Hulu Sungai Tengah. Dalam hal ini, Pemerintah Kabupaten Hulu Sungai Tengah berencana untuk membangun Bendungan Pancur Hanau di Sungai Barabai sehingga diharapkan dapat mereduksi debit banjir di Kota Barabai. Kalibrasi koefisien pengaliran dan debit banjir pada bulan Juni tahun 2013 sangat diperlukan dalam desain Bendungan Pancur Hanau dan penentuan ketinggian muka air sebagai peringatan dini bahaya banjir. Metode yang digunakan untuk menentukan koefisien pengaliran menggunakan persamaan Dr. Kawakami. Dalam kalibrasi debit banjir pada DAS Barabai menggunakan metode analisis hidrolika dan analisis hidrologi. Metode penentuan ketinggian muka air sebagai peringatan dini bahaya banjir menggunakan penelusuran banjir di atas pelimpah. Hasilnya koefisien pengaliran pada periode ulang 100 tahun sebesar 0,895 dan debit banjir yang setara pada bulan juni tahun 2013 di DAS Barabai sebesar 605,64 $\mathrm{m}^{3} / d t$. Ketinggian muka air banjir di atas Pelimpah Bendungan Pancur Hanau sebagai peringatan dini bahaya banjir untuk kondisi siaga 1, siaga 2 dan siaga 3 masing-masing sebesar 1,55 m, 1,65 m dan 1,78 m. Dengan adanya pembangunan Bendungan Pancur Hanau di Sungai Barabai, maka reduksi debit banjir $Q_{100,} Q_{1000}$ dan $Q_{P M F}$ masing-masing sebesar 11,70\%, 11,19\% dan 9,75\%.
\end{abstract}

Kata Kunci : Pengendalian banjir, sistem peringatan dini, bendungan Pancur Hanau.

\section{PENDAHULUAN}

Pada Bulan Juni 2013, banjir besar melanda Kota Barabai Kabupaten Hulu Sungai Tengah karena meluapnya Sungai Barabai, yang mana mengakibatkan kerusakan di sempadan sungai dan banjir menggenangi Kota Barabai. Sungai Barabai adalah anak Sungai Negara dan merupakan bagian dari SWS Barito dengan catchment area seluas $173,00 \mathrm{~km}^{2}$ dan panjang sungai utama 40,73 km. Hulu dari Sungai Barabai terletak di Gunung Periok, Gunung Panitiranggang Hulu dan Tilai, kemudian mengalir ke arah barat menuju Danau Bangkau dan selanjutnya mengalir menuju Sungai Negara. Kondisi Sungai Barabai sekarang semakin menunjukkan adanya permasalahan pada sistem sungai yang harus segera ditangani. Banjir yang tiap tahun terjadi di daerah sekitar aliran sungai sudah menyebabkan kerugian

Correspondence: Eddy Prabowo

Email : eddyprabowobanjarmasin@gmail.com yang cukup besar baik materi ataupun kerugian non fisik bahkan korban jiwa, terutama terhambatnya rencana dan pelaksanaan pembangunan daerah-daerah. Kejadian banjir pada Bulan Juni 2013 ini tercatat pada Automatic Water Level Recorder (AWLR) Pos Baruh Batung yang terletak di Kecamatan Hantakan Kabupaten Hulu Sungai Tengah.

Oleh karena itu pada penelitian ini akan mengangkat permasalahan mengenai banjir di Sungai Barabai dan upaya pengendalian banjir jangka panjang, yakni pada tahun 2015 Pemerintah Kabupaten Hulu Sungai Tengah berencana untuk membangun Bendungan Pancur Hanau di Sungai Barabai sehingga diharapkan dapat mereduksi debit banjir serta mengurangi kerusakan dan korban jiwa. Kalibrasi koefisien pengaliran dan debit banjir pada bulan Juni tahun 2013 sangat diperlukan dalam desain Bendungan Pancur Hanau untuk mereduksi banjir dan penentuan ketinggian 
muka air di atas pelimpah sebagai peringatan dini bahaya banjir

\section{METODE PENELITIAN}

\subsection{Kalibrasi Debit Banjir}

Adapun langkah kalibrasi debit banjir DAS Barabai ialah sebagai berikut:

a. Analisa curah hujan rerata daerah.

b. Melakukan uji kesesuaian distribusi frekuensi dengan metode Chi-Square dan Smirnov Kolmogorov.

c. Menghitung curah hujan rancangan dengan mengunakan distribusi Gumbel Tipe I dan Log Pearson Tipe III.

d. Menganalisa Hidrograf Satuan Sintetis.

e. Menentukan distribusi hujan jam-jaman

f. Menentukan Koefisien limpasan

g. Menghitung debit banjir rencana

h. Menghitung debit banjir menggunakan analisa hidrolika

\subsection{Penelusuran Banjir Di Atas Pelimpah Bendungan Pancur Hanau}

Adapun langkah penelusuran banjir di atas pelimpah Bendungan Pancur Hanau ialah sebagai berikut:

a. Menghitung debit banjir rencana dengan koefisien pengaliran terkalibrasi

b. Menghitung Lengkung Kapasitas Waduk

c. Menentukan tinggi dan lebar pelimpah

d. Melakukan penelusuran banjir di atas pelimpah

\section{HASIL DAN PEMBAHASAN}

\subsection{Kalibrasi Debit}

3.1.1 Curah Hujan Rerata Daerah

Ketersediaan data hujan yang digunakan dalam penelitian ini adalah mulai tahun 1978 hingga 2006 berupa pencatatan manual dari stasiun hujan mangunang, intangan dan batu tangga. Metode penentuan besarnya pengaruh tiap stasiun terhadap DAS digunakan Metode Polygon Thiessen.

\subsubsection{Curah Hujan Rancangan}

Pada penelitian ini digunakan metode perhitungan curah hujan rancangan gumbel tipe I dan log pearson tipe III. Berdasarkan penelitian Benson (1968) dan Beard (1974) menunjukkan bahwa metode log pearson tipe
III dan log normal yang menunjukkan hasil yang baik (Harto, 1993). Analisis curah hujan rancangan untuk 30 DAS di pulau jawa yang dilakukan Sri Harto $\mathrm{Br}$ menunjukan bahwa $66,4 \%$ mengikuti agihan log pearson tipe III, log normal dan normal masing-masing sebesar $30,3 \%$ dan 3,3\% (Harto, 1993). Sehingga dalam penelitian ini digunakan analisis curah hujan rancangan metode log pearson tipe III.

Tabel 1. Curah Hujan Rancangan Gumbel Tipe I

\begin{tabular}{ccc}
\hline $\mathrm{T}(\mathrm{thn})$ & $\mathrm{Y}$ & $\mathrm{XT}(\mathrm{mm})$ \\
\hline 1,01 & $-1,529$ & 52,41 \\
2 & 0,367 & 102,37 \\
5 & 1,500 & 132,25 \\
10 & 2,250 & 152,03 \\
20 & 2,970 & 171,00 \\
25 & 3,219 & 177,56 \\
50 & 3,912 & 195,83 \\
100 & 4,605 & 214,09 \\
1000 & 6,908 & 274,78 \\
\hline
\end{tabular}

Tabel 2. Curah Hujan Log Rancangan Pearson Tipe III

\begin{tabular}{ccc}
\hline $\mathrm{T}(\mathrm{thn})$ & $\mathrm{k}$ & $\mathrm{XT}(\mathrm{mm})$ \\
\hline 1,01 & $-2,087$ & 59,77 \\
2 & $-0,054$ & 101,84 \\
5 & 0,822 & 128,11 \\
10 & 1,311 & 145,60 \\
20 & 1,674 & 160,15 \\
25 & 1,856 & 167,96 \\
50 & 2,222 & 184,88 \\
100 & 2,560 & 201,99 \\
1000 & 3,558 & 262,34 \\
\hline
\end{tabular}

\subsubsection{Uji Kesesuaian Distribusi}

Uji kesesuaian distribusi frekuensi dilakukan untuk menguji data hujan rerata daerah DAS Barabai, dimana uji secara vertikal menggunakan metode chi square dan uji secara horisontal menggunakan metode smirnov kolmogorov.

Dari hasil perhitungan metode chi square $\mathrm{X}^{2}{ }_{\text {max }}=11.6$; sedangkan $\mathrm{X}^{2}$ kritis $=43.8$ (dengan tingkat kepercayaan $\alpha=95 \%$ ). Karena $X^{2}{ }_{\max }<$ $\mathrm{X}^{2}$ kritis maka uji data dapat diterima.

Dari hasil perhitungan metode smirnov kolmogorov $\mathrm{D}_{\max }=0.11$; sedangkan $\mathrm{D}_{\text {kritis }}=$ 0.24 (dengan tingkat kepercayaan $\alpha=95 \%$ ). Karena $D_{\max }<D_{\text {kritis }}$ maka uji data dapat diterima. 


\subsubsection{Hidrograf Satuan Sintetis}

Dalam penelitian ini digunakan tiga buah metode dalam perhitungan hidrograf satuan sintetis, yakni nakayasu, gama I dan Snyder. Adapun hasil perbandingan ketiga HSS tersebut disajikan pada Gambar 3.

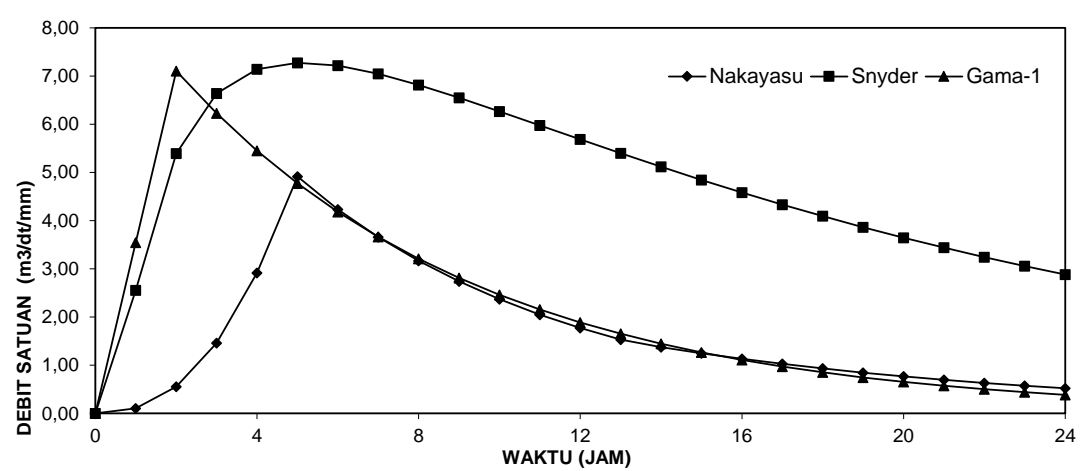

Gambar 1 Perbandingan Hidrograf Satuan Sintetis

Gambar 3 menunjukan bahwa debit puncak HSS Nakayasu memiliki nilai debit puncak yang paling kecil di antara HSS Gama I dan HSS Snyder. Sedangkan waktu puncak HSS Gama I paling cepat terjadi dibandingkan HSS Nakayasu dan HSS Snyder. Dari ketiga HSS ini akan dilakukan coba-coba untuk mengkalibrasi debit banjir rencana DAS Barabai di Desa Teluk Betung, dan HSS yang sesuai kalibrasi debit di Desa Teluk Betung ialah HSS metode Nakayasu.

\subsubsection{Koefisien Pengaliran}

Kondisi bagian hulu DAS Barabai merupakan pegunungan curam dan termasuk dalam katagori DAS berbentuk paralel yang mempunyai corak dimana dua buah jalur DAS bersatu di bagian hilir sehingga banjir akan terjadi di bagian hilir, dan setelah dilakukan beberapa kali trial error kalibrasi debit banjir rencana DAS Barabai di Desa Teluk Betung maka hasil analisis koefisien pengaliran yang sesuai ialah sesuai persamaan Dr. Kawakami. Adapun persamaan Dr. Kawakami yang diambil ialah di daerah DAS bagian tengah untuk kondisi sungai biasa dengan rumus $\mathrm{f}=1$ $-5,65 / \mathrm{Rt}^{(3 / 4)}$. Dari hasil analisis didapatkan besarnya koefisien pengaliran untuk $\mathrm{Q}_{1,01}, \mathrm{Q}_{2}$, $\mathrm{Q}_{5}, \mathrm{Q}_{10}, \mathrm{Q}_{20}, \mathrm{Q}_{25}, \mathrm{Q}_{50}, \mathrm{Q}_{100}, \mathrm{Q}_{1000}$ masingmasing sebesar 0.737, 0.824, 0.852, 0.865, $0.874,0.879,0.887,0.895$ dan 0.913 .

Tabel 3. Rumus Koefisien Pengaliran Dr. Kawakami

\begin{tabular}{llllll}
\hline Dae rah & Kondisi & $\begin{array}{l}\text { Curah } \\
\text { Hujan }(\mathbf{m m})\end{array}$ & \multicolumn{2}{l}{ Koefisien Pengaliran } \\
& Sungai & & $\mathrm{f}=1-$ & 15,7 & $\mathrm{Rt}^{\wedge}(3 / 4)$ \\
Hulu & & & $\mathrm{f}=1-$ & 5,65 & $/ \mathrm{Rt}^{\wedge}(3 / 4)$ \\
Tengah & sungai biasa & & $\mathrm{f}=1-$ & 7,2 & $/ \mathrm{Rt}^{\wedge}(3 / 4)$ \\
Tengah & sungai di zone lava & & $\mathrm{f}=1-$ & 3,14 & $/ \mathrm{Rt}^{\wedge}(3 / 4)$ \\
Tengah & & $\mathrm{Rt}>200 \mathrm{~mm}$ & $\mathrm{f}=1-$ & 6,6 & $/ \mathrm{Rt}^{\wedge}(3 / 4)$ \\
\hline
\end{tabular}

\subsubsection{Curah Hujan Efektif}

Analisis curah hujan efektif jam-jaman digunakan untuk mencari limpasan langsung.
Dalam penelitian ini sebaran hujan yang diambil ialah sebaran 7 jam berdasarkan rumus mononobe (Tabel 4). 
Tabel 4. Distribusi Curah Hujan Efektif Jam-jaman Dan Koefisien Pengaliran

\begin{tabular}{ccccccccccc}
\hline \multirow{2}{*}{$\begin{array}{c}\text { Waktu } \\
\text { (jam) }\end{array}$} & $\begin{array}{c}\text { Sebaran } \\
(\%)\end{array}$ & \multicolumn{10}{c}{ Kala Ulang (Tahun) } \\
\cline { 3 - 11 } & 1,01 & 2 & 5 & 10 & 20 & 25 & 50 & 100 & 1000 \\
\hline 1 & 0,52 & 23,04 & 43,85 & 57,03 & 65,86 & 73,21 & 77,17 & 85,76 & 94,46 & 125,26 \\
2 & 0,14 & 5,99 & 11,40 & 14,82 & 17,12 & 19,03 & 20,06 & 22,29 & 24,55 & 32,56 \\
3 & 0,10 & 4,20 & 8,00 & 10,40 & 12,01 & 13,35 & 14,07 & 15,64 & 17,22 & 22,84 \\
4 & 0,08 & 3,34 & 6,37 & 8,28 & 9,56 & 10,63 & 11,20 & 12,45 & 13,71 & 18,18 \\
5 & 0,06 & 2,82 & 5,38 & 6,99 & 8,07 & 8,97 & 9,46 & 10,51 & 11,58 & 15,35 \\
6 & 0,06 & 2,47 & 4,70 & 6,11 & 7,06 & 7,84 & 8,27 & 9,19 & 10,12 & 13,42 \\
7 & 0,05 & 2,21 & 4,20 & 5,46 & 6,31 & 7,01 & 7,39 & 8,22 & 9,05 & 12,00 \\
\hline C.H Log Pearson III (mm) & 59,77 & 101,84 & 128,11 & 145,60 & 160,15 & 167,96 & 184,88 & 201,99 & 262,34 \\
Koefisien Pengaliran & 0,737 & 0,824 & 0,852 & 0,865 & 0,874 & 0,879 & 0,887 & 0,895 & 0,913 \\
\multicolumn{1}{l}{ Hjn Eff Jam-jaman $(\mathrm{mm})$} & 44,06 & 83,89 & 109,10 & 125,98 & 140,05 & 147,62 & 164,05 & 180,69 & 239,61 \\
\hline
\end{tabular}

\subsubsection{Debit Banjir Rencana}

Dalam perhitungan debit banjir rencana akan dihitung debit banjir rencana berbagai kala ulang $\left(\mathrm{Q}_{1,01}, \mathrm{Q}_{2}, \mathrm{Q}_{5}, \mathrm{Q}_{10}, \mathrm{Q}_{20}, \mathrm{Q}_{25}, \mathrm{Q}_{50}\right.$, $\mathrm{Q}_{100}, \mathrm{Q}_{1000}$ ), adapun dalam perhitungannya merupakan gabungan beberapa hasil analisa sebelumnya yakni hidrograf satuan sintetis, curah hujan rancangan serta curah hujan efektif jam-jaman, dimana hasil debit banjir rencana tersebut akan diklabrasi dengan debit yang dihasilkan dari analisa hidrolika. Debit Banjir rencana hasil perhitungan dapat dilihat pada Gambar 4.

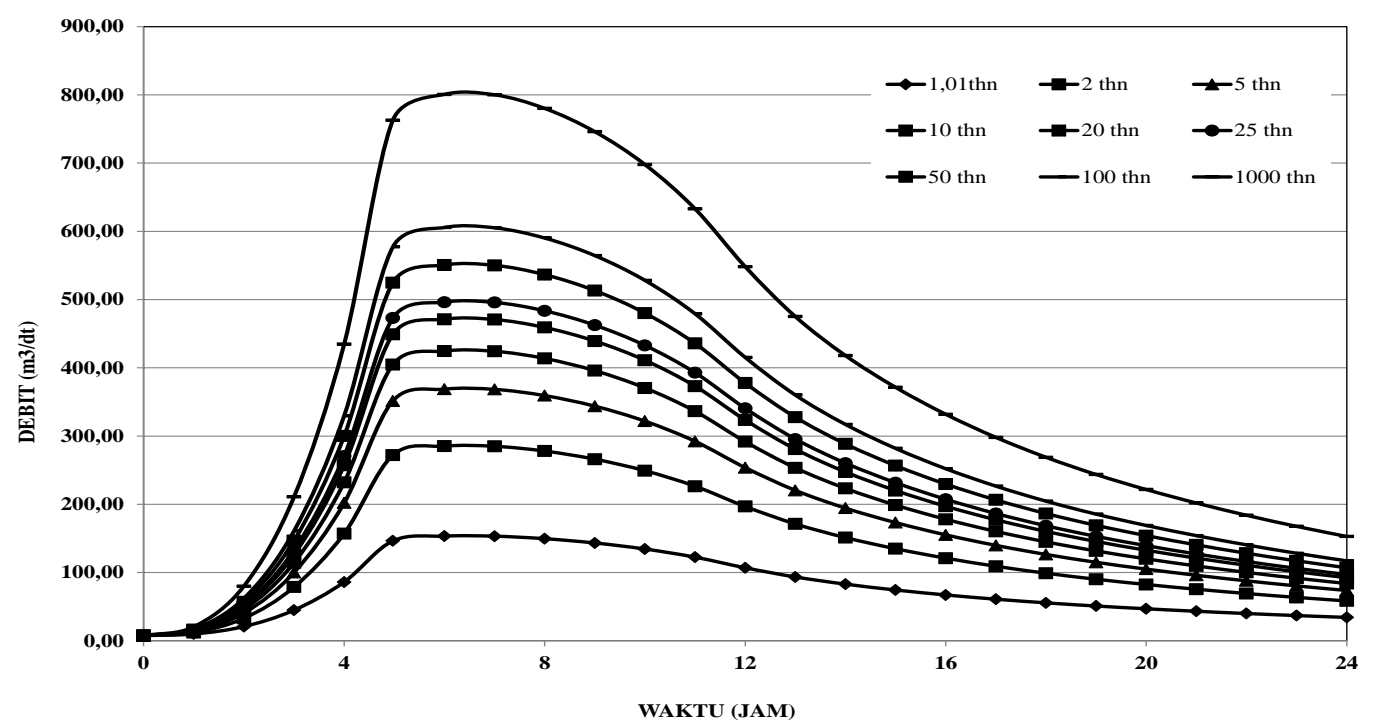

Gambar 2. Debit Banjir Rencana Berbagai Kala Ulang

\subsubsection{Kalibrasi Debit Banjir Rencana}

Setelah diketahui besarnya debit banjir rencana berbagai kala ulang, maka akan dilakukan kalibrasi debit banjir rencana menggunakan analisa hidrolika. Kalibrasi ini diambil pada titik Sungai Barabai di Desa Teluk Betung. Hasil titik kalibrasi debitdapat dilihat pada Gambar 5. Adapun parameter hidrolika dari analisis hidrolika ialah sebagai berikut :
- Lebar dasar sungairerata $(B)=17,21 \mathrm{~m}$

- Kemiringan tanggul $(\mathrm{m})=1: 1$

- Tinggi muka air(h) $\quad=6,18 \mathrm{~m}$

- Luas penampang(A) $\quad=144,61 \mathrm{~m}^{2}$

- Perimeter basah(P) $\quad=4,17 \mathrm{~m}$

- Jari-jari hidrolis(R) $\quad=4,17 \mathrm{~m}$

- Slope sungai $(\mathrm{s}) \quad=0,018$

- Koefisien manning(n) $\quad=0,025$

- Kecepatan aliran (v) $\quad=4,41 \mathrm{~m} / \mathrm{dt}$

- Tinggi garis energi $(\mathrm{He}) \quad=7,17 \mathrm{~m}$

- $\operatorname{Debit}(\mathrm{Q}) \quad=638,03 \mathrm{~m}^{3} / \mathrm{dt}$ 


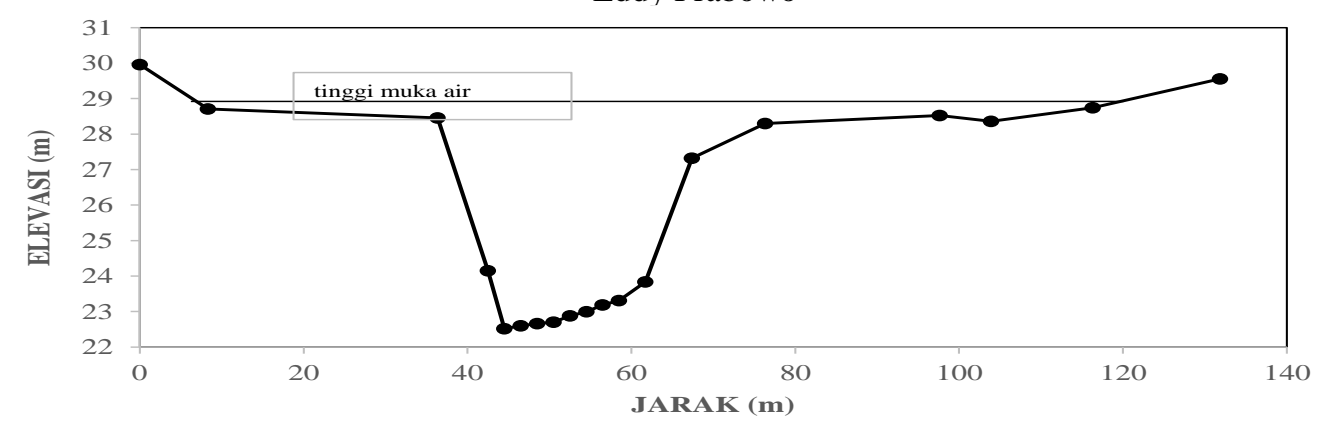

Gambar 3. Cross Section Sungai Barabai (Titik Kalibrasi Debit)

Dari hasil analisis hidrolika, debit yang didapatkan dengan analisis hidrolika sebesar 638,03 $\mathrm{m}^{3} / \mathrm{dt}$. Debit ini mendekati debit hasil perhitungan dengan analisis hidrologi yakni debit banjir rencana kala ulang 100 tahun sebesar 605,64 $\mathrm{m}^{3} / \mathrm{dt}$. Dari kedua analisis tersebut tersebut, maka debit banjir yang setara pada bulan Juni 2013 ialah debit dengan kala ulang 100 tahun sebesar $605,64 \mathrm{~m}^{3} / \mathrm{dt}$ dengan menggunakan koefisien limpasan Dr. Kawakami Daerah DAS bagian tengah untuk kondisi sungai biasa dengan rumus $\mathrm{f}=1-$ $5,65 / \operatorname{Rt}(3 / 4)$ sebesar 0,895 .

\subsection{Penelusuran Banjir Di Atas Pelimpah Bendungan Pancur Hanau}

\subsubsection{DAS Bendungan Pancur Hanau}

DAS Bendungan Pancur Hanau memiliki luas DAS sebesar $70,69 \mathrm{~km}^{2}$ dan panjang sungai utama sebesar $25,90 \mathrm{~km}$. DAS Bendungan Pancur Hanau berada di sebelah hulu pos AWLR Baruh Batung. Gambar lokasi DAS Bendungan Pancur Hanau dapat dilihat pada Gambar 6.

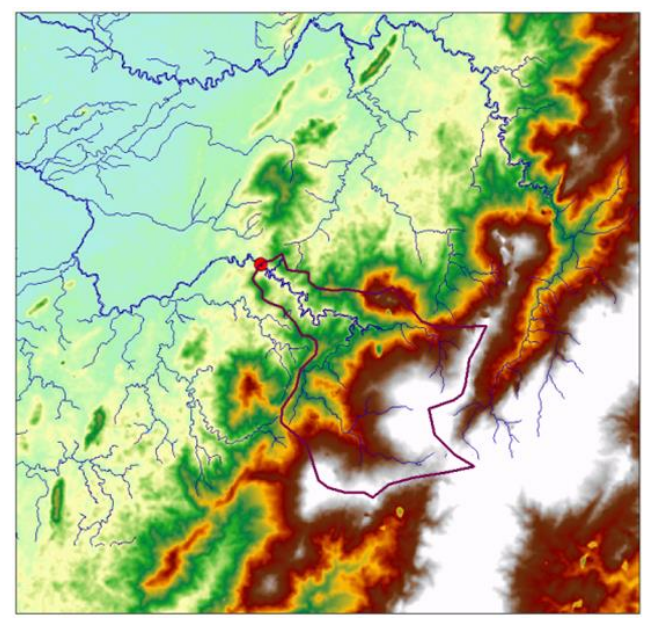

Gambar 4. DAS Bendungan Pancur Hanau

\subsubsection{Curah Hujan Rancangan}

Analisis curah hujan rancangan menggunakan metode perhitungan curah hujan rancangan gumbel tipe I dan log pearson tipe III (Tabel 5 dan 6). Pada penelitian ini digunakan metode log pearson tipe III.

Tabel 5. Curah Hujan Rancangan Gumbel Tipe I

\begin{tabular}{ccc}
\hline $\mathrm{T}$ (thn) & $\mathrm{Y}$ & $\mathrm{XT}(\mathrm{mm})$ \\
\hline 1,01 & $-1,529$ & 68,59 \\
2 & 0,367 & 110,23 \\
5 & 1,500 & 135,12 \\
10 & 2,250 & 151,61 \\
20 & 2,970 & 167,42 \\
25 & 3,219 & 172,88 \\
50 & 3,912 & 188,10 \\
100 & 4,605 & 203,33 \\
1000 & 6,908 & 253,90 \\
\hline
\end{tabular}

Tabel 6. Curah Hujan Rancangan Log Pearson Tipe III

\begin{tabular}{ccc}
\hline $\mathrm{T}(\mathrm{thn})$ & $\mathrm{k}$ & $\mathrm{XT}(\mathrm{mm})$ \\
\hline 1,01 & $-2,572$ & 64,627 \\
2 & 0,056 & 112,680 \\
5 & 0,854 & 133,382 \\
10 & 1,239 & 144,717 \\
20 & 1,499 & 152,874 \\
25 & 1,628 & 157,123 \\
50 & 1,868 & 165,286 \\
100 & 2,074 & 172,664 \\
1000 & 2,621 & 193,850 \\
\hline
\end{tabular}

3.2.3 Curah Hujan Rancangan PMP (Probable Maximum Precipitation)

Curah hujan rancangan Probable Maximum Precipitation (PMP) digunakan untuk menghitung besarnya debit banjir rencana Probable Maximum Flood (QPMF) 
Bendungan Pancur Hanau. Standar keamanan bendungan yang ditetapkan oleh komisi bendungan saat ini adalah QPMF. QPMF nantinya akan digunakan sebagai control water level pelimpah Bendungan Pancur Hanau yang menggunakan debit desain $\mathrm{Q}_{1000}$. Besarnya curah hujan rancangan PMP Bendungan Pancur Hanau ialah sebesar $328,38 \mathrm{~mm}$.

\subsubsection{Hidrograf Satuan Sintetis}

Hidrograf satuan sintetias yang digunakan pada DAS Bendungan Pancur Hanau menggunakan metode HSS Nakayasu.

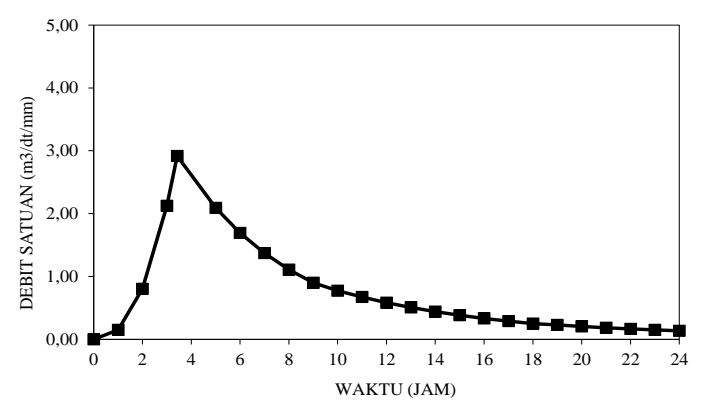

Gambar 5. HSS Nakayasu DAS Bendungan Pancur Hanau

\subsubsection{Curah Hujan Efektif}

Analisis curah hujan efektif jam-jaman digunakan untuk mencari limpasan langsung. Dalam penelitian ini sebaran hujan yang diambil ialah sebaran 7 jam berdasarkan rumus mononobe. Analisis curah hujan jam jaman dapat dilihat pada Tabel 7.

Tabel 7. Analisis Curah Hujan Efektif Jam-jaman

\begin{tabular}{cccccccccccc}
\hline \multirow{2}{*}{$\begin{array}{c}\text { Waktu } \\
\text { (jam) }\end{array}$} & $\begin{array}{c}\text { Sebaran } \\
(\%)\end{array}$ & \multicolumn{10}{c}{ Kala Ulang (Tahun) } \\
\cline { 3 - 12 } & 1,01 & 2 & 5 & 10 & 20 & 25 & 50 & 100 & 1000 & PMF \\
\hline 1 & 0,52 & 25,41 & 49,28 & 59,69 & 65,41 & 69,53 & 71,68 & 75,81 & 79,55 & 90,32 & 159,09 \\
2 & 0,14 & 6,60 & 12,81 & 15,51 & 17,00 & 18,07 & 18,63 & 19,71 & 20,68 & 23,47 & 41,35 \\
3 & 0,10 & 4,63 & 8,99 & 10,88 & 11,93 & 12,68 & 13,07 & 13,82 & 14,51 & 16,47 & 29,01 \\
4 & 0,08 & 3,69 & 7,15 & 8,66 & 9,49 & 10,09 & 10,40 & 11,00 & 11,55 & 13,11 & 23,09 \\
5 & 0,06 & 3,11 & 6,04 & 7,32 & 8,02 & 8,52 & 8,79 & 9,29 & 9,75 & 11,07 & 19,50 \\
6 & 0,06 & 2,72 & 5,28 & 6,40 & 7,01 & 7,45 & 7,68 & 8,12 & 8,52 & 9,68 & 17,05 \\
7 & 0,05 & 2,43 & 4,72 & 5,72 & 6,27 & 6,66 & 6,87 & 7,26 & 7,62 & 8,65 & 15,24 \\
\hline C.H. Rancangan & 64,63 & 112,68 & 133,38 & 144,72 & 152,87 & 157,12 & 165,29 & 172,66 & 193,85 & 328,38 \\
Koefisien Pengaliran & 0,752 & 0,837 & 0,856 & 0,865 & 0,870 & 0,873 & 0,877 & 0,881 & 0,891 & 0,927 \\
Hjn Eff Jam-jaman & 48,61 & 94,27 & 114,18 & 125,12 & 133,01 & 137,12 & 145,03 & 152,18 & 172,77 & 304,33 \\
\hline
\end{tabular}

\subsubsection{Debit Banjir Rencana}

Analisa debit banjir rencana dilakukan untuk debit banjir berbagai kala ulang. Hasil perhitungan debit banjir rencana DAS bendungan Pancur Hanau dapat dilihat pada Gambar 8.

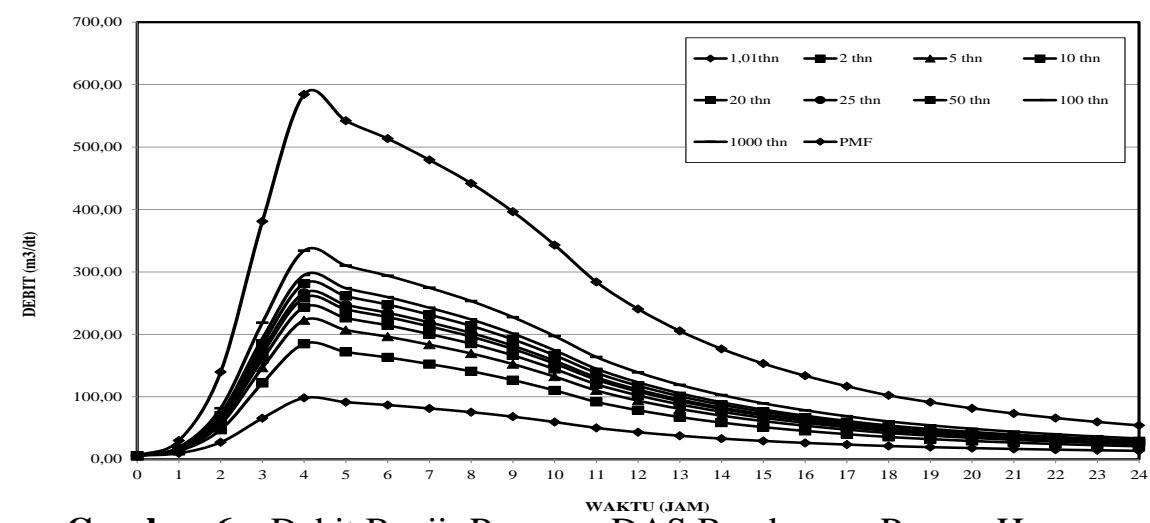

Gambar 6. Debit Banjir Rencana DAS Bendungan Pancur Hanau

\subsubsection{Lengkung Kapasitas}

Analisa lengkung kapasitas Bendungan Pancur Hanau dihitung dari peta bakosurtanal skala 1:50.000. Dari peta ini akan didapatkan hubungan antara tinggi muka air pada as 
bendungan dengan daerah genangan. Setelah teranalisis besarnya daerah genangan maka akan didapatkan juga hubungan antara tinggi muka air pada as bendungan dengan volume waduk. Berdasar laporan Studi Kelayakan (FS) Bendungan Pancur Hanau Sungai Barabai Kabupaten Hulu Sungai Tengah tahun 2015, Bendungan Pancur Hanau didesain mempunyai lebar pelimpah sebesar $50,00 \mathrm{~m}$ dan ketinggian pelimpah 35,00 $\mathrm{m}$ dari dasar sungai. Volume tampungan efektif sebesar 13,22 juta $\mathrm{m}^{3}$ dan luas daerah genangan sebesar 74,73 ha.Lengkung kapasitas DAS bendungan Pancur Hanau dapat dilihat pada Gambar 7.

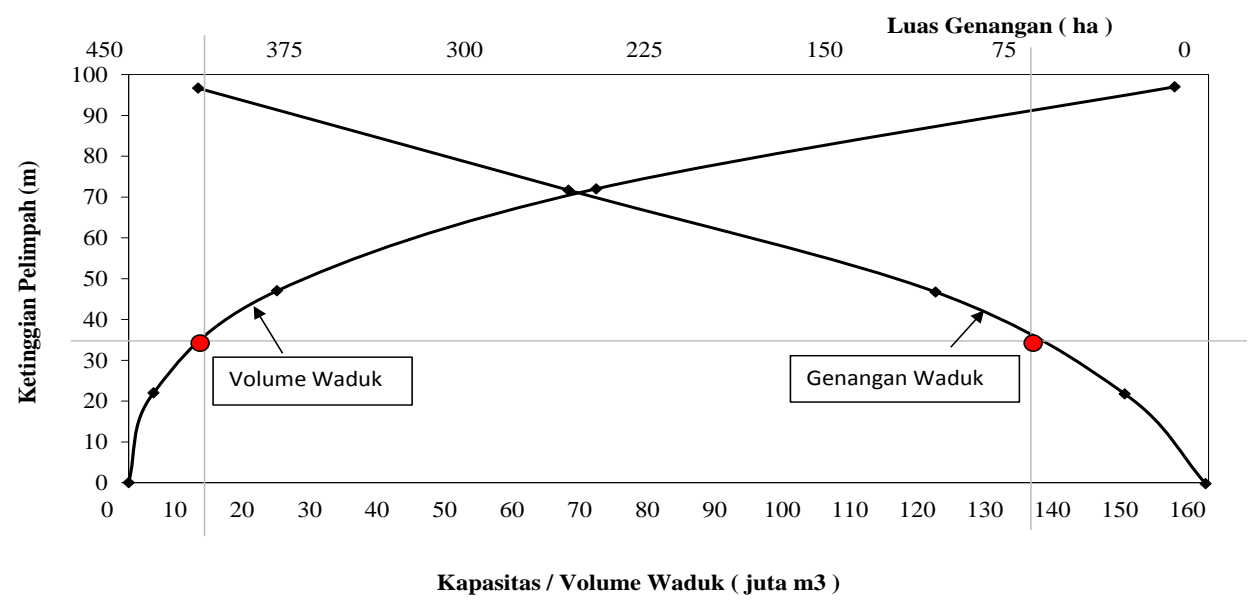

Gambar 7. Lengkung Kapasitas DAS Bendungan Pancur Hanau

\subsubsection{Penelusuran Banjir Di Atas Pelimpah \\ Penelusuran banjir dilakukan untuk debit banjir berbagai kala ulang. Setelah dilakukan penelusuran banjir, maka dari hasil Bendungan Pancur Hanau masih mampu melewatkan QPMF tersebut. Gambar penelusuran banjir di atas pelimpah bendungan} penelusuran QPMF, bahwa kapasitas pelimpah

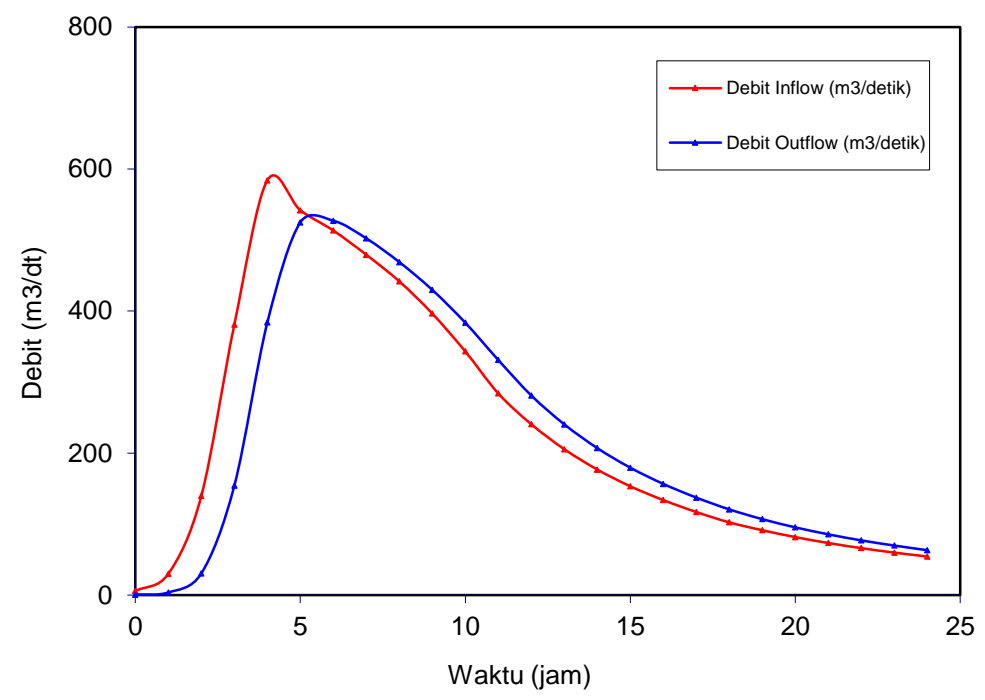

Gambar 7. Penelusuran Banjir Di Atas Pelimpah Bendungan Pancur Hanau QPMF

Adapun rekapitulasi hasil penelusuran banjir di atas pelimpah Bendungan Pancur Hanau disajikan pada Tabel 8. 
Tabel 8. Rekapitulasi Hasil Penelusuran Banjir Di Atas Pelimpah Bendungan Pancur Hanau

\begin{tabular}{llrrrrrrrrrr}
\hline Kala Ulang & Tahun & PMF & 1000 & 100 & 50 & 25 & 20 & 10 & 5 & 2 & 1,01 \\
\hline Tinggi Pelimpah & $\mathrm{m}$ & 35,00 & 35,00 & 35,00 & 35,00 & 35,00 & 35,00 & 35,00 & 35,00 & 35,00 & 35,00 \\
Lebar Pelimpah & $\mathrm{m}$ & 50,00 & 50,00 & 50,00 & 50,00 & 50,00 & 50,00 & 50,00 & 50,00 & 50,00 & 50,00 \\
Debit Inflow Max & $\mathrm{m} 3 / \mathrm{dt}$ & 584,22 & 334,14 & 295,01 & 281,41 & 266,38 & 258,56 & 243,57 & 222,77 & 184,93 & 98,12 \\
Debit Outflow Max & $\mathrm{m} 3 / \mathrm{dt}$ & 527,25 & 296,77 & 260,51 & 247,83 & 234,00 & 226,69 & 212,87 & 193,56 & 158,73 & 81,98 \\
Tinggi Air Di Atas Pelimpah & $\mathrm{m}$ & 2,85 & 1,94 & 1,78 & 1,72 & 1,65 & 1,62 & 1,55 & 1,46 & 1,28 & 0,82 \\
Kecepatan di Atas Pelimpah & $\mathrm{m} / \mathrm{dt}$ & 3,71 & 3,06 & 2,93 & 2,88 & 2,83 & 2,80 & 2,74 & 2,65 & 2,49 & 2,00 \\
Kapasitas Pelimpah & $\%$ & 90,25 & 88,81 & 88,30 & 88,07 & 87,84 & 87,67 & 87,40 & 86,88 & 85,84 & 83,55 \\
Reduksi Debit Banjir & $\%$ & 9,75 & 11,19 & 11,70 & 11,93 & 12,16 & 12,33 & 12,60 & 13,12 & 14,16 & 16,45 \\
\hline
\end{tabular}

\subsubsection{Early Warning System}

Berdasarkan hasil analisis hidrologi dan analisis hidrolika pada DAS Barabai di Desa Teluk Betung menunjukan bahwa debit banjir yang terjadi pada bulan juni tahun 2013 mendekati debit banjir kala ulang 100 tahun sebesar 605,64 $\mathrm{m}^{3} / \mathrm{dt}$. Dari hasil analisis tersebut sebaiknya alat early warning system (EWS) dipasang di Bendungan Pancur Hanau dan disetting akan memberikan informasi bahaya banjir apabila terjadi debit banjir kala ulang 10 tahun (siaga 1), 25 tahun (siaga 2), dan 100 tahun (siaga 3) dengan ketinggian muka air di atas pelimpah bendungan masingmasing sebesar $1,55 \mathrm{~m}, 1,65 \mathrm{~m}$ dan $1,78 \mathrm{~m}$.

\section{KESIMPULAN}

Dari hasil penelitian terdapat beberapa kesimpulan sebagai berikut:

1. Nilai koefisien pengaliran pada DAS Barabai untuk periode kala ulang 100 tahun sebesar 0,895 .

2. Debit banjir di Sungai Barabai berdasarkan pencatatan tinggi muka air Pos Baruh Batung pada bulan Juni tahun 2013 sebesar 638,03 $\mathrm{m}^{3} / \mathrm{dt}$, sedangkan debit banjir berdasarkan analisis hidrologi sebesar $605,64 \mathrm{~m}^{3} / \mathrm{dt}$.

3. Ketinggian muka air banjir di atas pelimpah Bendungan Pancur Hanau sebagai peringatan dini bahaya banjir untuk kondisi siaga 1, siaga 2 dan siaga 3 masing-masing sebesar $1,55 \mathrm{~m}, 1,65 \mathrm{~m}$ dan $1,78 \mathrm{~m}$.

4. Dengan adanya pembangunan Bendungan Pancur Hanau di Sungai Barabai, maka debit banjir $\mathrm{Q}_{100}, \mathrm{Q}_{1000}$ dan QPMF yang akan direduksi masing-masing sebesar $11,70 \%, 11,19 \%$ dan $9,75 \%$.

\section{DAFTAR RUJUKAN}

AryadiE. V., P. T. Juwono, D. Priyantoro, R. Asmarato. (2014). Analisa Keruntuhan Bendungan Gondang Dengan Menggunakan Program Zhong Xing HY21. Jurnal Teknik Pengairan5(1):114.

Chow, V. T. 1989. Hidrolika Saluran Terbuka. Jakarta: Erlangga.

Harto, S. Br,. 1993. Analisis Hidrologi. Jakarta: Gramedia Pustaka Utama.

Hadisusanto, N,. 2010. Aplikasi Hidrologi. Yogyakarta: Jogja Mediautama.

Hendri, A. 2015. Analisis Metode Intensitas Hujan Pada Stasiun Hujan Pasar Kampar Kabupaten Kampar. Annual Civil Enggineering Seminar 2015:298.

Kartikasari, D. 2015. Analisis Curah Hujan Untuk Pendugaan Debit Puncak Dengan Metode Haspers Pada DAS Kali Blawi Kabupaten Lamongan. Jurnal Teknika7(2):696.

Limantara, L M,. 2010. Hidrologi Praktis. Bandung: Lubuk Agung.

Soemarto, C.D. 1987. Hidrologi Teknik. Surabaya: Usaha Nasional.

Soewarno. 1995. HIDROLOGI: Aplikasi MetodeStatistik untuk Analisa Data. Bandung: Nova

Sosrodarsono, S. dan K Takeda. 1989. Bendungan Type Urugan. Jakarta: Pradnya Paramita. 
Siby E. P. 2016. Studi Perbandingan Hidrograf Satuan Sintetik Pada Daerah Aliran Sungai Ranoyapo. Jurnal Sipil Statik 1(4):261-263.
Victory, D. E., Siswanto dan Trimaijon. 2016. Kajian Lebar Bangunan Pelimpah Tipe Lengkung Terhadap Elevasi Muka Banjir (Studi Kasus Waduk Tenayan). Jom FTEKNIK3(2):4. 